\title{
The First 109 Minutes: 9/11 and the U.S. Air Force
}

\section{Priscilla D. Jones}

\author{
AIR \\ FPRCE \\ Muserums \\ PROGRAM \\ Washington, D.C. \\ 2011
}

